\title{
PROBLEMATIKA PENGUKURAN PANGSA PASAR
}

\author{
Kajian Putusan Nomor 502 K/PDT.SUS/2010
}

\section{THE PROBLEMATICS IN MEASUREMENT OF MARKET SHARE}

\author{
An Analysis of Court Decision Number 502 K/PDT.SUS/2010
}

\author{
Mukti Fajar Nur Dewata \\ Fakultas Hukum Universitas Muhammadiyah Yogyakarta \\ Jl. Lingkar Selatan Tamantirto Kasihan Bantul Yogyakarta 55183 \\ E-mail: muktifajar_umy@yahoo.co.id
}

Naskah diterima: 31 Oktober 2017; revisi: 4 Desember 2017; disetujui 18 Desember 2017

http://dx.doi.org/10.29123/jy.v10i3.287

\begin{abstract}
ABSTRAK
Putusan Nomor 09/KPPU-L/2009 menilai telah terdapat bukti yang sah dan meyakinkan bahwa PT CI telah melanggar Undang-Undang Nomor 5 Tahun 1999 tentang Larangan Praktik Monopoli dan Persaingan Usaha Tidak Sehat. Adapun pasal yang dilanggar adalah Pasal 17 ayat (1) yang memuat ketentuan mengenai larangan bagi pelaku usaha untuk melakukan penguasaan pasar, dan Pasal 25 ayat (1) yang memuat ketentuan terkait dengan posisi dominan. Putusan KPPU tersebut kemudian dibatalkan oleh Mahkamah Agung melalui Putusan Nomor 502 K/PDT.SUS/2010 yang menyatakan bahwa PT CI tidak terbukti melanggar pasal-pasal tersebut. Penelitian ini mengkaji mengenai perdebatan penafsiran klausul tentang penguasaan atas produksi dan pemasaran sehingga mengakibatkan monopoli dan persaingan usaha tidak sehat, dan perbedaan pengukuran pangsa pasar yang dijadikan dasar oleh KPPU dan Mahkamah Agung sehingga menghasilkan putusan yang berbeda. Penelitian ini dilakukan secara yuridis normatif yang mengkaji berbagai bahan hukum, serta dianalisis secara deskriptif komparatif. Temuan penelitian ini menunjukkan bahwa ada perbedaan cara penafsiran teks Undang-Undang Anti Monopoli antara KPPU dan Mahkamah Agung. KPPU menggunakan standar pangsa
\end{abstract}

pasar di kota tertentu di mana PT CI membuka usaha, Mahkamah Agung menggunakan standar pangsa pasar dengan wilayah nasional.

Kata kunci: persaingan usaha, monopoli, pengukuran pangsa pasar, posisi dominan.

\section{ABSTRACT}

Decision of Commission for the Supervision of Business Competition (KPPU) Number 09/KPPU-L/2009 stated that there were valid and convincing evidences that PT CI has violated Law Number 5 of 1999 regarding Prohibition of Monopolistic Practices and Unfair Business Competition Article 17 paragraph (1) regarding the prohibition for business actors to control the markets, and Article 25 paragraph (1) containing provisions relating to dominant position. The decision was subsequently annulled by the Supreme Court by the Decision Number 502 K/PDT.SUS/2010 stating that PT CI was not proven to have violated those articles. This research examines as follows: first, debate on interpretation of clauses about the control of production and markets resulting in monopoly and unfair business competition, second, differences in measurement of market share applied by the KPPU and the Supreme Court as underpinning two different decisions. This 
analysis was conducted using the method of normative juridical approach by examining various law materials, and analyzing through descriptive comparative method. The result of this analysis showed that there is a difference in ways of interpreting the text of Anti-monopoly Law between the KPPU and the Supreme Court. The KPPU used market share standards in certain cities where PT CI opened a business while Supreme Court used market share standards in national territory.

Keywords: business competition, monopoly, market share measurement, dominant position.

\section{PENDAHULUAN}

\section{A. Latar Lelakang}

Salah satu strategi bisnis untuk menguasai pasar adalah dengan melakukan akuisisi perusahaan. Selain untuk mengurangi pesaing, akuisisi juga dianggap sebagai cara cepat mengekspansi usaha, karena perusahaan yang diambil alih telah memiliki pasar dan produk unggulan. Namun strategi ini perlu dilakukan secara hati-hati. Sebab jika mengakibatkan monopoli, maka dianggap melanggar hukum persaingan (Undang-Undang tentang Larangan Praktik Monopoli dan Persaingan Usaha Tidak Sehat). Seperti kasus akuisisi yang dilakukan oleh PT CI terhadap PT AR, di mana tindakan ini dianggap melanggar Undang-Undang Nomor 5 Tahun 1999 tentang Larangan Praktik Monopoli dan Persaingan Usaha Tidak Sehat.

Pasca akuisisi, PT CI diduga menguasai pasar retail $48,3 \%$ atau meningkat dari sebelumnya $37,9 \%$. PT CI juga diduga menguasai $66,7 \%$ pasarpemasok dari sebelumnya $44,72 \%$ (finance.detik.com). Sedangkan data yang diperoleh AC Nielsen menjelaskan bahwa sebelum mengakuisisi PT AR, pangsa pasar produk makanan PT CI hanya 5\%. Namun setelah mengakuisisi, diperkirakan pangsa pasar yang akan dikuasai adalah 7\%. Walaupun PT CI bersama dengan PT AR belum menguasai produk makanan lebih dari 50\%, tetapi pasar HC adalah menjadi pelaku usaha dominan. PT
CI pada tahun 2007 telah memiliki 31 gerai. Maka PT CI menjadi pelaku usaha hypermarket yang mempunyai gerai tertinggi. Setelah mengakuisisi PT AR, PT CI menjadi perusahaan yang dominan menguasai pangsa pasar lebih dari $50 \%$.

Berdasarkan data dan laporan yang telah diterima, Komisi Pengawas Persaingan Usaha (KPPU) melakukan pemeriksaan awal terhadap bisnis PT CI dan ditemukan pangsa pasar PT CI melonjak melebihi 50\%. KPPU menuding kenaikan pangsa pasar membuat perusahaan itu leluasa menetapkan biaya tinggi kepada pemasok. Pemasok dikenakan biaya promosi, diskon promosi, dan biaya rabat. Dalam sidang KPPU tanggal 4 November 2009, majelis KPPU menyatakan PT CI terbukti secara sah dan meyakinkan melanggar Pasal 17 ayat (1) dan Pasal 25 ayat (1) huruf a Undang-Undang Nomor 5 Tahun 1999.

Dasar pertimbangan hukum dari KPPU bahwa PT CI dianggap melanggar Pasal 17 ayat (1) karena melakukan penguasaan pasar ditafsirkan hanya pada kota-kota di mana PT CI mempunyai outlet. Berdasarkan bukti-bukti yang diperoleh selama pemeriksaan, perusahaan ritel PT CI menguasai 57,99\%, sehingga secara hukum memenuhi kualifikasi menguasai pasar dan mempunyai posisi dominan. Sedangkan PT CI dianggap bersalah melanggar Pasal 25 ayat (1) huruf a ditafsirkan oleh KPPU karena 
terbukti menetapkan syarat-syarat perdagangan. Selanjutnya majelis KPPU memerintahkan PT CI melepas seluruh kepemilikan pada pihak yang tidak terafiliasi serta menghukum membayar denda Rp25 miliar. Namun kasus tersebut tidak berhenti pada putusan KPPU.

Pihak PT CI mengajukan keberatan ke Pengadilan Negeri Jakarta Selatan. Pada tanggal 17 Februari 2010, Pengadilan Negeri Jakarta Selatan memenangkan keberatan PT CI atas putusan KPPU dan menyatakan perusahaan ritel asing itu tidak terbukti melakukan monopoli. Putusan pengadilan negeri tersebut disambut KPPU dengan mengajukan kasasi ke Mahkamah Agung. Pada tanggal 21 Oktober 2010, Mahkamah Agung melalui Putusan Nomor 502 K/PDT.SUS/2010 menolak kasasi KPPU dan menguatkan putusan Pengadilan Negeri Jakarta Selatan.

Dasar pertimbangan majelis kasasi terkait dengan dugaan pelanggaran Pasal 17 ayat (1) tidak terbukti karena diukur dengan skala pasar retail nasional. Sedangkan pelanggaran pada Pasal 25 menurut Mahkamah Agung harus memenuhi semua kesalahan yang dijelaskan dalam ayat (1) huruf a sampai dengan huruf $\mathrm{c}$. Dari latar belakang tersebut, nampak adanya perbedaan cara pengukuran pasar dan penafsiran undang-undang antara KPPU dan Mahkamah Agung.

\section{B. Rumusan Masalah}

Perbedaan putusan hukum antara KPPU dan Mahkamah Agung mengenai kasus akuisisi PT CI terhadap PT AR menarik untuk dikaji dengan menfokuskan permasalahan sebagai berikut:
1. Bagaimana penafsiran terhadap klausul "penguasaan atas produksi dan pemasaran sehingga mengakibatkan monopoli dan persaingan usaha tidak sehat" dalam Pasal 17 ayat (1) Undang-Undang Nomor 5 Tahun 1999?

2. Bagaimana standar pengukuran pangsa pasar untuk menentukan penguasaan atas produksi dan pemasaran sehingga mengakibatkan monopoli dan persaingan usaha tidak sehat dalam Pasal 17 ayat (1) Undang-Undang Nomor 5 Tahun 1999?

\section{Tujuan dan Kegunaan}

Tujuan penulisan jurnal ini adalah:

1. Mengetahui penafsiran klausul tentang penguasaan atas produksi dan pemasaran sehingga mengakibatkan monopoli dan persaingan usaha tidak sehat dalam Pasal 17 ayat (1) Undang-Undang Nomor 5 Tahun 1999, dan

2. Mengetahui standar pengukuran pangsa pasar untuk menentukan penguasaan atas produksi dan pemasaran sehingga mengakibatkan monopoli dan persaingan usaha tidak sehat dalam Pasal 17 ayat (1) Undang-Undang Nomor 5 Tahun 1999.

Kegunaan penelitian ini diharapkan dapat memberikan kontribusi teoritis terhadap pengembangan ilmu hukum, khususnya hukum persaingan usaha. Selain itu diharapkan memberikan manfaat praktis sebagai rujukan bagi para penegak hukum persaingan usaha dalam menganalisis dan menangani kasus-kasus persaingan usaha berkaitan dengan penafsiran kaidah hukum dan standar pengukuran pangsa pasar. 


\section{Tinjauan Pustaka}

1. Monopoli dan Persaingan Usaha Tidak Sehat

Secara etimologi, monopoli berasal dari bahasa Yunani, yaitu "monos," yang artinya satu atau sendiri, dan "polein" yang artinya menjual atau penjual. Berdasarkan etimologi monopoli tersebut dapat diartikan bahwa monopoli adalah kondisi di mana hanya ada satu penjual yang menawarkan satu barang dan jasa tertentu (Margono, 2009: 6). Dari sudut pandang ekonomi, monopoli adalah suatu jenis struktur pasar (market structure) di mana ada satu perusahaan dengan banyak pembeli, tanpa adanya produk substitusi serta hambatan bagi pesaing untuk masuk pasar (barrier to entry) (Hermansyah, 2008: 39).

Undang-Undang Nomor 5 Tahun 1999 dalam Pasal 1 angka 1 menyebutkan monopoli adalah penguasaan atas produksi dan atau pemasaran barang dan atau atas penggunaan jasa tertentu oleh satu pelaku usaha atau satu kelompok pelaku usaha. Inti dari semua pengertian tersebut dapat dikatakan bahwa monopoli adalah penguasaan atas transaksi bisnis dari hulu ke hilir oleh satu atau kelompok usaha.

Monopoli merupakan perwujudan dari kondisi persaingan usaha yang tidak sehat (Nugroho, 2014: 6). Di Indonesia, secara historis kedudukan monopoli yang pernah ada pada masa lalu lahir karena adanya fasilitas yang diberikan oleh pemerintah serta ditempuh melalui praktik bisnis yang tidak sehat (unfair business practice) seperti persekongkolan penetapan harga melalui kartel, menetapkan mekanisme yang menghalangi terbentuknya kompetisi, menciptakan barrier to entry, dan juga terbentuknya integrasi horizontal dan vertikal (Wiradiputra dalam Nugroho, 2014).
Terdapat beberapa jenis monopoli dalam suatu kegiatan ekonomi, antara lain:

1. Monopoli yang terjadi karena dikehendaki oleh undang-undang (monopoly by law), yaitu berupa:

a. Monopoli negara untuk menguasai bumi dan air berikut kekayaan alam yang terkandung di dalamnya, monopoli atas cabang produksi yang menguasai hajat hidup orang banyak;

b, Hak istimewa dan perlindungan hukum dalam jangka waktu tertentu terhadap pelaku usaha yang memenuhi syarat tertentu, dalam hal ini perlindungan atas hak kekayaan intelektual.

2. Monopoli yang lahir dan tumbuh secara alamiah karena didukung oleh iklim dan lingkungan usaha yang sehat (monopoly by nature);

3. Monopoli yang diperoleh melalui lisensi dengan menggunakan mekanisme kekuasaan (monopoly by license);

4. Monopoli karena terbentuknya struktur pasar akibat perilaku tidak jujur (Nugroho, 2014: 239).

Dalam Undang-Undang Nomor 5 Tahun 1999, monopoli merupakan salah satu dari beberapa jenis kegiatan yang dilarang yang berdampak merugikan persaingan pasar. "Kegiatan" yang dimaksud di sini merupakan suatu usaha, aktivitas, tindakan, atau perbuatan hukum secara sepihak yang dilakukan oleh pelaku usaha tanpa melibatkan pelaku usaha lainnya (Yani \& Widjaja, 1999: 31). 
Monopoli tidak hanya diartikan mencakup struktur pasar dengan hanya satu pemasok atau pembeli di pasar yang bersangkutan, sebab hal ini jarang sekali terjadi, jangkauan kata monopoli dapat dilihat jika seseorang yang monopolis menguasai pangsa pasar lebih dari 50\%, dengan demikian, pada pasar tersebut masih ada pelaku usaha (pesaing) namun terdapat satu atau dua pelaku usaha yang lebih menguasai (Rokan, 2012: 150).

\section{Pangsa Pasar dan Dominasi Pasar}

Pasal 1 angka 9 Undang-Undang Nomor 5 Tahun 1999 merumuskan pengertian "pasar" adalah lembaga ekonomi di mana para pembeli dan penjual baik secara langsung maupun tidak langsung dapat melakukan transaksi perdagangan barang dan atau jasa. Department of Justice and the Federal Trade Commission USA mendefinisikan "pasar" sebagai "a product or group of products and a geographic area in which it is producer or sold such that a hypothetical profit-maximising firm, not subject to price regulation, that was the only present and future producer or seller of those products in that area likely would impose at least a 'small but significant transitory' increase in price, assuming the terms of sale of all other products are held constant" (Horizontal Merger Guidelines, 1992: 4).

Cakupan pengertian "pasar" menurut Undang-Undang Nomor 5 Tahun 1999 dapat dikategorikan dalam dua perspektif, yaitu:

1. Pasar berdasarkan geografis, yaitu pasar yang penetapannya berdasarkan aspek geografis atau daerah/teritori yang merupakan lokasi pelaku usaha dalam menjalankan kegiatan usahanya;
2. Pasar berdasarkan produk, yaitu pasar berdasarkan produk terkait dengan kesamaan, atau kesejenisan dan/ atau tingkat substitusinya (Nugroho, 2014: 386).

Berdasarkan luas wilayah kegiatannya, pasar dapat dibedakan menjadi:

1. Pasar lokal adalah pasar yang daerah pemasarannya hanya meliputi daerah tertentu, dan pada umumnya hanya menawarkan barang yang dibutuhkan oleh masyarakat di sekitarnya;

2. Pasar nasional adalah pasar yang daerah pemasarannya meliputi wilayah satu negara;

3. Pasar regional adalah pasar yang daerah pemasarannya meliputi beberapa negara pada wilayah tertentu. Pasar ini biasanya di bawah naungan wadah kerja regional;

4. Pasar internasional adalah pasar yang daerah pemasarannya mencakup seluruh kawasan dunia. Pasar ini juga disebut pasar dunia (Illiyyun, 2012: 14).

Pengertian "pangsa pasar" menurut ketentuan Pasal 1 angka 13 Undang-Undang Nomor 5 Tahun 1999 adalah persentase nilai jual atau beli barang atau jasa tertentu yang dikuasai oleh pelaku usaha pada pasar bersangkutan dalam tahun kalender tertentu. Sementara business dictionary mengartikan market share adalah "a percentage of total sales volume in a market captured by a brand, product, or company."

Blundell, Griffith, \& Reenen (1999: 293) mendefinisikan market share sebagai "the 
company's sales divided by total industry sales," dengan kata lain, market share adalah rasio total penjualan perusahaan jika dibandingkan dengan total penjualan di industri yang sejenis.

Mengenai penguasaan pasar, UndangUndang Nomor 5 Tahun 1999 tidak merumuskan secara khusus mengenai pengertian dari "penguasaan pasar," namun demikian, penguasaan pasar merupakan kegiatan yang dilarang karena dapat mengakibatkan praktik monopoli dan persaingan usaha yang tidak sehat. Larangan ini sebagaimana diatur dalam Pasal 19, 20, dan 21 Undang-Undang Nomor 5 Tahun 1999. Meskipun tidak dirumuskan berapa besar penguasaan pasar atau berapa pangsa pasar suatu pelaku usaha, namun demikian suatu perusahaan yang menguasai pangsa pasar, pasti mempunyai posisi dominan di pasar (Lubis et al., 2009: 39).

Pengertian posisi dominan dijelaskan dalam Undang-Undang Nomor 5 Tahun 1999 Pasal 25 yang merumuskan bahwa pelaku usaha memiliki posisi dominan apabila:

1. Satu pelaku usaha atau satu kelompok pelaku usaha menguasai $50 \%$ atau lebih pangsa pasar satu jenis barang atau jasa tertentu; atau

2. Dua atau tiga pelaku usaha atau kelompok pelaku usaha menguasai $75 \%$ atau lebih pangsa pasar satu jenis barang atau jasa tertentu.

Dari definisi tersebut, meskipun tidak dihubungkan secara langsung, dapat disimpulkan bahwa suatu posisi dominan cenderung dimiliki oleh pelaku usaha yang secara fisik telah menguasai pangsa pasar secara dominan. Dominasi pasar didefinisikan oleh Cour \& Møllgaard (2002) sebagai “traditionally dominance has been approximated by large market share. As a rule of thumb, a firm with a market share of more than forty per cent would be thought to have a dominant position. " Dalam hal ini Cour \& Møllgaard berpendapat bahwa pelaku usaha yang menguasai pangsa pasar lebih dari $40 \%$ dapat diduga telah memiliki posisi dominan.

Pihak yang dapat melakukan penguasaan pasar adalah pelaku usaha yang memiliki market power, yaitu pelaku usaha yang dapat menentukan harga barang dan atau jasa di pasar yang bersangkutan. Kriteria penguasaan pasar tersebut tidak harus $100 \%$, akan tetapi satu pelaku usaha atau satu kelompok pelaku usaha yang telah menguasai lebih dari 50\% pangsa pasar satu jenis produk tertentu sudah dapat dikatakan memiliki market power (Nugroho, 2014: 255).

Indikator market power menurut Bishop \& Walker (2010: 62), antara lain sebagai berikut:

1. Jumlah pemasok yang bersaing, pangsa pasar, dan pemusatan kekuatan;

2. Hambatan masuk dan persaingan potensial;

3. Hambatan untuk ekspansi;

4. Menghitung kekuatan pembeli;

5. Diferensiasi produk;

6. Sifat oligopolistik dan interaksi antar pelaku usaha.

Menurut Undang-Undang Nomor 5 Tahun 1999, kegiatan penguasaan pasar yang dilarang adalah ketika terjadi penolakan atau menghalang-halangi pelaku usaha lain untuk melakukan kegiatan usaha yang sama. Menolak atau menghalang-halangi pelaku usaha tertentu dapat diklasifikasikan sebagai berikut: 
1. Menolak pesaing (refusal to deal), yaitu menolak atau menghalangi pelaku usaha pesaing dalam hal melakukan usaha yang sama dalam pasar yang bersangkutan;

2. Menghalangi konsumen, yaitu menghalangi konsumen dari pelaku usaha pesaing untuk meneruskan hubungan bisnis dengan pelaku usaha pesaing;

3. Pembatasan peredaran produk;

4. Diskriminasi terhadap pelaku usaha pesaing;

5. Melakukan jual rugi (predatory pricing);

6. Penetapan biaya secara curang (MA RI, 2005: 78-80).

\section{Akuisisi: Strategi Bisnis atau Monopoli?}

Pasal 1 angka 11 Undang-Undang Nomor 40 Tahun 2007 tentang Perseroan Terbatas menyebutkan akuisisi adalah perbuatan hukum yang dilakukan oleh badan hukum atau orang perorangan untuk mengambil alih saham perseroan yang mengakibatkan beralihnya pengendalian saham atas perseroan.

Akuisisi merupakan pengambil alihan kepemilikan atau pengendalian atas saham perusahaan oleh perusahaan lain. Namun perusahaan pengambil alih atau yang diambil alih tetap eksis sebagai badan hukum yang terpisah (Irawanto, 2016: 2). Akuisisi juga sebagai strategi pertumbuhan eksternal dan merupakan jalur cepat untuk mengakses pasar baru atau produk baru tanpa harus membangun dari nol. Secara garis besar, tujuan merger dan akuisisi sebagai berikut:

1. Motif ekonomi yaitu seberapa besar perusahaan mampu menciptakan suatu nilai bagi perusahaan dan pemegang saham;

2. Motif sinergi yaitu di mana perusahaan melakukan akuisisi adalah untuk memperoleh mafaat lebih;

3. Motif diversifikasi yaitu merupakan strategi pemberagaman bisnis;

4. Motif non-ekonomi yaitu akuisisi didasarkan pada pertimbangan lain seperti prestige dan ambisi (Moin, 2010: 48).

Berdasarkan hubungan usaha serta ada atau tidaknya kesamaan sifat dari dua entitas usaha yang melakukan akuisisi. Reksohadiprodjo (1999) membagi akuisisi ke dalam tiga kelompok besar, yaitu:

1. Akuisisi horizontal yaitu akuisisi yang dilakukan oleh suatu badan usaha yang lain, tetapi masih dalam bisnis yang sama. Hal ini bertujuan untuk meminimalkan tingkat persaingan yang ada;

2. Akuisisi vertikal yaitu akuisisi pemasok atau pelanggan badan usaha yang dibeli;

3. Akuisisi konglomerat yaitu akuisisi badan usaha yang tidak ada hubungannya sama sekali dengan badan usaha pembeli.

Dari berbagai penjelasan di atas, dapat dilihat bahwa motif sebuah perusahaan melakukan akuisisi adalah sebagai strategi bisnis untuk memperluas usaha. Motif Alibaba mengakuisisi Lazada misalnya, dilakukan untuk memperluas pasar ke kawasan Asia Tenggara. 
Presiden Alibaba menyatakan: "Dengan investasi di Lazada, Alibaba menambah akses ke platform yang memiliki basis konsumen besar dan terus bertumbuh di luar China." (Fajrina, 2016).

Salah satu CEO XL menyatakan tujuan utama PT XL mengakuisisi PT Axis adalah untuk menggunakan spektrum tambahan di $1.800 \mathrm{Mhz}$ supaya bisa digunakan untuk membangun jaringan data. Frekuensi $1.800 \mathrm{MHz}$ sebagai sumber masa depan untuk layanan data menggunakan teknologi 4G. Dengan mengakuisisi Axis ini langkah strategis untuk dapatkan frekuensi tersebut" (Mailanto, 2016). Jadi, strategi bisnis akuisisi tidak selalu dilakukan dengan motif untuk monopoli, tetapi lebih pada sifat dasar bisnis, yaitu untuk meningkatkan keuntungan serta menjaga keberlanjutan usaha.

\section{Penafsiran Hukum terhadap Klausul Per Se Illegal dan Rule of Reason}

Penafsiran hukum adalah suatu upaya yang pada dasarnya menerangkan, menjelaskan, dan menegaskan baik dalam arti memperluas maupun membatasi/mempersempit pengertian hukum yang ada dalam rangka penggunaannya untuk memecahkan masalah atau persoalan yang sedang dihadapi. Istilah lain untuk penafsiran hukum adalah interpretasi hukum (Halim, 2005: 81).

Beberapa bentuk dari penafsiran/interpretasi hukum adalah:

1. Penafsiran gramatikal yaitu interpretasi ketentuan peraturan perundang-undangan berdasarkan tata bahasa;

2. Penafsiran historis yaitu interpretasi berdasarkan terbentuknya peraturan perundang-undangan;
3. Penafsiran sosiologis yaitu interpretasi berdasarkan keadaan masyarakat pada saat kejadian berlangsung; dan

4. Penafsiran perbandingan yaitu interpretasi berdasarkan pasal yang satu dengan pasal yang lain (Mertokusumo, 2003: 170-175).

Persoalan penafsiran muncul ketika hukum (dalam hal ini undang-undang) tidak selalu hadir dari klausul yang tunggal dan mono tafsir. Untuk melakukan hal tersebut, dalam literasi hukum dikenal pendekatan per se illegal dan rule of reason. Per se illegal adalah suatu pendekatan yang secara an sich dan lebih menitikberatkan pada perilaku, tanpa memperhitungkan situasi kondisi dan akibatnya. Sedangkan pendekatan rule of reason adalah pendekatan yang mempertimbangkan dan memperhitungkan akibat negatif dari perilaku tersebut (Anggraini, 2003: 7-8). Kedua pendekatan tersebut sudah lazim digunakan dalam perumusan dan penafsiran hukum persaingan usaha untuk menilai apakah suatu tindakan tertentu dari pelaku usaha telah melanggar ketentuan Undang-Undang Nomor 5 Tahun 1999 atau tidak (Lubis et al., 2009: 55).

Kata "per se" secara terminologi berasal dari bahasa Latin yang berarti "it self, in itself, taken alone, by mean of itself, through itself, inherently, in isolation, un connected with other matters, simply as such, in its own nature without reference of its relation (Black, 1990: 1142).

Dalam hukum persaingan, per se illegal adalah istilah yang mengandung maksud bahwa jenis-jenis perjanjian tertentu, atau perbuatan-perbuatan tertentu dianggap anti kompetitif dan merugikan masyarakat tanpa perlu dibuktikan bahwa perbuatan tersebut secara nyata mengakibatkan persaingan usaha 
tidak sehat (Nugroho, 2014: 693). Rule of reason merupakan kebalikan dari per se illegal, artinya bahwa suatu perbuatan yang dituduhkan melanggar hukum persaingan, pencari fakta harus mempertimbangkan kondisi di sekitar kasus untuk memutuskan apakah perbuatan itu mengakibatkan persaingan usaha tidak sehat.

Dalam Undang-Undang Nomor 5 Tahun 1999, pendekatan rule of reason ini dapat dilihat dari ketentuan pasal-pasalnya, yakni pencantuman frasa "yang dapat mengakibatkan" dan atau "patut diduga." Frasa tersebut menyiratkan perlunya penelitian secara lebih mendalam, apakah suatu tindakan dapat menimbulkan praktik monopoli yang bersifat menghambat persaingan. Sedangkan penerapan pendekatan per se illegal biasanya dipergunakan dalam pasalpasal yang menyatakan istilah "dilarang” tanpa frasa “...yang dapat mengakibatkan ...” Misalnya pemeriksaan terhadap perjanjian penetapan harga (Pasal 5) dianggap menggunakan pendekatan per se illegal (Lubis et al., 2009: 55). Pendekatan per se illegal menyatakan bahwa setiap perjanjian atau kegiatan usaha tertentu sebagai ilegal, tanpa memerlukan pembuktian lebih lanjut atas dampak yang ditimbulkan dari perjanjian (Khemani \& Shapiro, $1999: 5$ ).

\section{METODE}

Penelitian ini menggunakan tipe penelitian yuridis normatif, yaitu penelitian yang mengkaji kaidah, teori asas-asas, dan peraturan perundangundangan serta putusan peradilan. Penelitian ini menggunakan pendekatan perundang-undangan (statute approach) dan pendekatan kasus (case approach) (Marzuki, 2016: 60), di mana fokus penelitian ini adalah kasus akuisisi PT AR oleh PT CI melalui Putusan KPPU Nomor 09/
KPPU-L/2009 dan Putusan Nomor: $502 \mathrm{~K} /$ PDT.SUS/2010. Analisis penelitian ini adalah deskriptif komparatif, yaitu memaparkan dan memperbandingkan Putusan KPPU dan Putusan Mahkamah Agung terhadap kasus akuisisi PT CI yang diteliti.

\section{HASIL DAN PEMBAHASAN}

\section{Penafsiran Klausul tentang Penguasaan Atas Produksi dan Pemasaran}

Dalam kasus akuisisi PT AR oleh PT CI, terdapat dua putusan dengan isi yang berbeda, yaitu:

a. Putusan KPPU Nomor 09/KPPU-L/2009 memutuskan telah terdapat bukti yang sah dan meyakinkan bahwa PT CI telah melanggar Pasal 17 ayat (1) tentang penguasaan atas produksi dan atau pemasaran barang dan atau jasa yang dapat mengakibatkan terjadinya praktik monopoli dan atau persaingan usaha tidak sehat, dan Pasal 25 ayat (1) tentang penyalahgunaan posisi dominan Undang-Undang Nomor 5 Tahun 1999;

b. Putusan Nomor 502 K/PDT.SUS/2010 memutuskan membatalkan Putusan KPPU Nomor 09/KPPU-L/2009 dan menyatakan bahwa PT CI tidak terbukti melanggar Pasal 17 ayat (1) dan Pasal 25 ayat (1) UndangUndang Nomor 5 Tahun 1999.

Sebelumnya dijelaskan secara utuh, teks peraturan yang menjadi pokok perkara adalah sebagai berikut: Pasal 17 ayat (1) yaitu: Pelaku usaha dilarang melakukan penguasaan atas produksi dan atau pemasaran barang dan atau jasa yang dapat mengakibatkan terjadinya praktik monopoli dan atau persaingan usaha tidak sehat. 
Dalam ayat (2) dijelaskan bahwa pelaku usaha patut diduga atau dianggap melakukan penguasaan atas produksi dan atau pemasaran barang dan atau jasa apabila:

a. Barang dan atau jasa yang bersangkutan belum ada substitusinya; atau

b. Mengakibatkan pelaku usaha lain tidak dapat masuk ke dalam persaingan usaha barang dan atau jasa yang sama; atau

c. Satu pelaku usaha atau satu kelompok pelaku usaha menguasai lebih dari 50\% pangsa pasar satu jenis barang atau jasa tertentu.

Selanjutnya Pasal 25 ayat (1) menyebutkan pelaku usaha dilarang menggunakan posisi dominan baik secara langsung maupun tidak langsung untuk:

a. Menetapkan syarat-syarat perdagangan dengan tujuan untuk mencegah dan atau menghalangi konsumen memperoleh barang dan atau jasa yang bersaing, baik dari segi harga maupun kualitas; atau

b. Membatasi pasar dan pengembangan teknologi; atau

c. Menghambat pelaku usaha lain yang berpotensi menjadi pesaing untuk memasuki pasar bersangkutan.

Dalam Pasal 25 ayat(2) dijelaskan mengenai pelaku usaha memiliki posisi dominan apabila:

a. Satu pelaku usaha atau satu kelompok pelaku usaha menguasai 50\%; atau

b. Lebih pangsa pasar satu jenis barang atau jasa tertentu; atau

c. Dua atau tiga pelaku usaha atau kelompok pelaku usaha menguasai $75 \%$ atau lebih pangsa pasar satu jenis barang atau jasa tertentu.

Argumentasi KPPU dalam memberikan putusan bahwa PT CI telah melanggar kedua pasal dengan alasan:

a. Berdasarkan pemeriksaan KPPU, terbukti bahwa hampir semua barang yang dijual di minimarket juga dijual di supermarket, hampir semua barang yang dijual di supermarket juga dijual di hypermarket. Semua barang yang dijual di hypermarket juga dijual di grosir. Sebagian barang yang dijual di hypermarket juga dijual di departement store. Selain itu, barang-barang yangdijual di toko modern spesialis juga ada pada hypermarket atau grosir. Dengan demikian terbukti terdapat kesamaan barang yang dijual oleh PT CI dengan barang yang dijual oleh peritel modern lainnya. Hal ini memenuhi unsur Pasal 17 ayat (2) huruf a Undang-Undang Nomor 5 Tahun 1999, yatitu: barang dan atau jasa yang bersangkutan belum ada substitusinya;

b. KPPU menemukan bahwa pasca akuisisi, peningkatan market power PT CI disalahgunakan untuk menekan pemasok melalui berbagai ketentuan trading terms yang merugikan. Tingginya barrier to entry untuk memasuki pasar menyebabkan kesulitan bagi pemasok untuk memasuki pasar upstream. Hal ini memenuhi unsur Pasal 17 ayat (2) huruf b Undang-Undang Nomor 5 Tahun 1999, yaitu: mengakibatkan pelaku usaha lain tidak dapat masuk ke dalam persaingan usaha barang dan atau jasa yang sama;

c. Berdasarkan hasil pemeriksaan KPPU, pangsa pasar PT CI meningkat secara 
signifikan pasca akuisisi PT AR dari 40,82\% (2006) menjadi 57,99\% (2008). Hal ini memenuhi unsur Pasal 17 ayat (2) huruf c dan Pasal 25 ayat (2) UndangUndang Nomor 5 Tahun 1999, yaitu: satu pelaku usaha atau satu kelompok pelaku usaha menguasai lebih dari 50\% pangsa pasar satu jenis barang atau jasa tertentu;

d. KPPU menemukan bahwa pasca akuisisi, PT CI kemudian menetapkan berbagai syarat perdagangan (trading terms) kepada para pemasok sehingga memenuhi unsur pelanggaran Pasal 25 ayat (1) huruf a Undang-Undang Nomor 5 Tahun 1999.

Majelis hakim kasasi menyatakan bahwa PT CI tidak terbukti melanggar Pasal 17 dan Pasal 25 Undang-Undang Nomor 5 Tahun 1999, dengan menggunakan analisis argumentasi hukum material sebagai berikut:

1. Dalam menentukan ada atau tidaknya "penguasaan atas produksi dan atau pemasaran" harus memenuhi unsur yang termuat dalam Pasal 17 Undang-Undang Nomor 5 Tahun 1999 secara kumulatif. Apabila salah satu unsur tidak terpenuhi maka tuduhan pelanggaran tidak terbukti. Ketiga syarat yang diatur dalam Pasal 17 ayat (2) di atas dinyatakan tidak terbukti dengan penjelasan sebagai berikut:

a. Barang-barang yang dijual oleh PT CI merupakan barang yang terdapat banyak substitusi, atau sama dengan barang yang dijual oleh peritel modern lainnya baik yang berbentuk minimarket, supermarket, hypermarket, departement store, grosir, dan termasuk toko modern spesialis. Oleh karena itu, PT CI tidak mungkin mempunyai posisi monopoli karena barang yang dijual bukan barang eksklusif. Dengan demikian unsur melakukan penguasaan produksi dan atau pemasaran barang yang diatur dalam Pasal 17 ayat (2) huruf a Undang-Undang Nomor 5 Tahun 1999 tidak terbukti;

b. PT CI tidak pernah mengakibatkan pelaku usaha lain tidak dapat masuk ke dalam persaingan usaha ritel modern dan untuk menjual barang yang sama. Berdasarkan analisis Mahkamah Agung terdapat bukti bahwa tidak ada hambatan masuk pasar ( $n o$ entry barrier) dalam sektor ritel modern di Indonesia. Hal ini karena jumlah peritel modern sangat banyak dan selalu bertambah dari waktu ke waktu. Selain itu, masingmasing dari peritel modern tersebut terus-menerus melakukan ekspansi untuk membuka lahan atau gerai baru tanpa hambatan sehingga setiap tahun jumlah gerainya bertambah banyak. Dengan demikian unsur Pasal 17 ayat (2) huruf b Undang-Undang Nomor 5 Tahun 1999 tidak terbukti.

Untuk menganalisis perbedaan kedua putusan di atas dapat dilihat dari: pertama, cara penafsiran secara tata bahasa (gramatikal) dengan melihat kalimat undang-undang secara utuh. Dalam Pasal 17 maupun Pasal 25 rincian unsurunsur perbuatan hukum dikalimatkan dalam ayat-ayatnya menggunakan kata "atau" bukan "dan." Sehingga unsur-unsur tersebut secara tata bahasa adalah pilihan (alternafif) bukan ke semuanya (kumulatif). Sehingga Putusan KPPU yang menyebutkan bahwa PT CI telah melanggar 
salah satu Pasal 25 ayat (1) huruf a sudah dapat dinyatakan bersalah. Begitu juga dengan Pasal 17 ayat (2) huruf b yang menurut Putusan Mahkamah Agung tidak terbukti, namun dengan jelas dapat dibuktikan oleh KPPU bahwa PT CI telah melanggar Pasal 17 ayat (2) huruf $b$.

Kedua, jika dilihat dari cara penafsiran historis yang bisa dilihat dari tujuan pengaturan Undang-Undang Nomor 5 Tahun 1999 disebutkan dalam Pasal 3 huruf b, yaitu: “...menjamin adanya kepastian kesempatan berusaha yang sama bagi semua pelaku usaha." Dari uraian tersebut bahwa Putusan KPPU adalah mencegah ketidakadilan sistem pasar dengan melarang adanya hambatan masuknya pelaku usaha ke dalam pasar dengan strategi bisnis PT CI yang menetapkan berbagai syarat perdagangan (trading terms) kepada para pemasok.

Ketiga, konteks entry barrier (menghambat masuknya pelaku usaha ke dalam pasar), KPPU menggunakan ketentuan Pasal 25 dirumuskan dengan pendekatan per se illegal, di mana PT CI terbukti secara formal telah memberikan syaratsyarat perdagangan (trading terms) kepada "para pemasok" yang merupakan perbuatan yang dilarang oleh Pasal 25 ayat (1) huruf a UndangUndang Nomor 5 Tahun 1999. Sedangkan dalam Putusan Mahkamah Agung menyatakan bahwa akuisisi PT CI terhadap PT AR berdasarkan Pasal 17 ayat (2) huruf b, yang dirumuskan dengan pendekatan rule of reason, "tidak mengakibatkan" pelaku usaha lain tidak dapat masuk ke dalam persaingan usaha barang dan atau jasa yang sama. Menurut pendapat saksi ahli Arindra A. Zainal dan Erman Rajagukguk, bahwa di waktu yang sama “pesaing lain” seperti Giant, Hypermart, Makro/ Lotte, Hero, Ramayana, Superindo, Indomaret, Alfamart, Circle K, ACE, Metro, dan Matahari terus berekspansi. Di sini nampak perbedaan pasal dan penafsiran yang digunakan antara Mahkamah Agung dan KPPU tentang prinsip entry barrier (hambatan masuk).

Penulis memberikan pendapat bahwa PT CI telah melakukan pelanggaran Pasal 25 ayat (1) huruf a karena terbukti telah menetapkan syarat-syarat perdagangan. Karena di setiap akhir kalimat ayat ini jelas dituliskan "atau," sehingga tidak harus semua dibuktikan bersalah secara kumulatif. Hal ini berakibat pelanggaran Pasal 17 ayat (2) huruf b jo. Pasal 25 ayat (1) huruf c yang mengatakan: "menghambat pelaku usaha lain yang berpotensi menjadi pesaing untuk memasuki pasar bersangkutan." Karena hukum persaingan secara substantif melarang segala bentuk hambatan bagi masuknya persaingan.

\section{Standar Pengukuran Pangsa Pasar Untuk Menentukan Penguasaan Atas Produksi dan Pemasaran}

KPPU dan Mahkamah Agung mengeluarkan putusan yang berbeda menggunakan dasar analisis pengukuran pangsa pasar. KPPU melakukan pengukuran kekuatan pasar dengan beberapa cara sebagai berikut:

1. Menilai ukuran atau skala usaha pelaku usaha dibandingkan ukuran/ skala usaha pelaku usaha lainnya. Ukuran tersebut dapat didasarkan pada nilai penjualan, kapasitas produksi, maupun kapasitas penjualan yang dapat diukur dari luas lahan penjualan. Di mana semakin besar lahan yang dikuasai oleh pelaku usaha dibandingkan pelaku usaha yang lain, maka semakin besar potensi pelaku usaha tersebut dominan di pasar bersangkutan; 
2. Mengukur pangsa pasar berdasarkan geografis dilihat dari nilai penjualan. Data yang dipakai dalam analisis adalah penjualan tiap outlet dari seluruh outlet yang ada.

3. KPPU menggunakan metode pengukuran rasio konsentrasi dengan pendekatan rasio konsentrasi empat perusahaan (CR4) dan HerfindahlHirschman Index (HHI). Metode CR4 merupakan ukuran yang biasa dipakai dalam melihat rasio konsentrasi empat perusahaan dengan nilai pangsa pasar terbesar. Metode $\mathrm{HHI}$ adalah pendekatan yang digunakan untuk mengukur tingkat konsentrasi di suatu industri. Penghitungannya adalah berdasarkan jumlah kuadrat dari pangsa pasar pelaku usaha yang ada dalam pasar bersangkutan. Dapat dirumuskan sebagai berikut:

$$
H=\sum_{i=1}^{N} s_{i}^{2}
$$

Di mana, $\mathrm{H}$ adalah nilai $\mathrm{HHI}$, si adalah pangsa pasar perusahaan $i$ di dalam sebuah pasar bersangkutan tertentu, dan $N$ adalah jumlah pelaku usaha. Dari angka HHI yang diperoleh dapat diklasifikasikan menjadi beberapa kategori yaitu:

a. HHI di bawah 1800: komisi mengeluarkan no objection letter;

b. HHI antara 1800 sampai dengan 3000: komisi melakukan penilaian menyeluruh;

c. HHI antara 3000 sampai dengan 4000: komisi mengeluarkan conditional no objection letter; d. HHI di atas 4000: komisi mengeluarkan objection letter.

Dalam perkara PT CI, sebelum akuisisi pada tahun 2007 tingkat HHI industri mencapai angka 2950,09 dengan nilai CR4 yang mencapai 93,36\% yang menandakan konsentrasi yang sangat tinggi dari suatu industri. Setelah akuisisi, yaitu pada tahun 2008, tingkat konsentrasi industri semakin tinggi lagi hingga mencapai angka HHI 3779,16 dan CR4 menjadi 96,70\%. Selain metode CR4 dan HHI yang digunakan oleh majelis KPPU, terdapat beberapa rumus lain yang dapat digunakan untuk menghitung pangsa pasar.

Seperti telah disinggung sebelumnya, Blundell, Griffith, \& Reenen (1999: 539) mendefinisikan market share sebagai "the company's sales divided by total industry sales." Dari pengertian ini, maka cara menghitung pangsa pasar atau market share adalah sebagai berikut:

\section{Firm's earnings $\times 100 \%$}

\section{Industries earnings}

Adapun metode lain yang dapat diterapkan untuk pengukuran pangsa pasar (Wulandari, 2016: 23) adalah sebagai berikut:

$$
\mathrm{Msi}=\underline{\mathrm{Si}} \times 100
$$

Dimana $M S i$ adalah pangsa pasar perusahaan $i \quad(\%), \quad S i$ merupakan kapasitas penjualan perusahaan $i$ (rupiah), serta Stot merupakan total penjualan seluruh perusahaan (rupiah). Pangsa pasar biasanya menunjukkan kekuatan pasar yang besar pula, dan sebaliknya pangsa pasar yang kecil berarti perusahaan memiliki pangsa pasar yang rendah yang nantinya akan tercipta persaingan pasar yang efektif. Sementara itu Mahkamah Agung dalam putusannya menggunakan data kajian pihak ketiga, yaitu data kajian AC Nielsen, 
MARS, dan Euromonitor. Metode AC Nielsen dalam mengkaji pangsa pasar tidak dijelaskan dalam putusan. Namun pangsa pasar yang digunakan adalah berdasarkan wilayah nasional. Arindra A. Zainal dalam keterangan ahlinya menyatakan bahwa cara menghitung pangsa pasar adalah dengan membandingkan rasio antara nilai penjualan satu perusahaan terhadap nilai penjualan pasar keseluruhan di mana perusahaan tersebut berada, rumusannya sebagai berikut:

Pangsa Pasar $=\underline{\text { Nilai Penjualan Perusahaan }}$ Total Penjualan Pasar

Dengan demikian, untuk menghitung pangsa pasar yang tepat adalah dengan menggunakan nilai penjualan pelaku usaha secara nasional, bukan hanya berdasarkan beberapa wilayah tertentu saja.

Undang-Undang Nomor 5 Tahun 1999 tidak memberikan cakupan pasar bersangkutan berdasarkan geografis. Akan tetapi Peraturan KPPU menyatakan bahwa pasar geografis ini terkait dengan jangkauan daerah pemasaran suatu produk. Perbedaan muncul dalam hal penentuan pasar bersangkutan ini, KPPU melakukan pengukuran hanya di wilayah di mana terdapat lokasi usaha PT CI yaitu DKI Jakarta, Bandung, Yogyakarta, Malang, Surabaya, dan Makassar. Menurut Ramadhany (2015: 65) dalam pasar geografis pengukuran terhadap pasar bersangkutan ditetapkan berdasarkan luas wilayah pemasaran produk oleh pelaku usaha. Sedangkan AC Nielsen melakukan pengukuran menggunakan data skala nasional seluruh Indonesia. Seperti yang dikatakan Arindra A. Zainal, bahwa definisi pasar bersangkutan adalah pasar ritel modern di seluruh Indonesia.

Kedua putusan tersebut memperlihatkan adanya perbedaan dalam menentukan pangsa pasar. KPPU menggunakan "penjualan tiap outlet dari seluruh outlet yang ada" di mana pasar dihitung berdasarkan kota-kota di mana ada usaha PT CI berada. Sedangkan Mahkamah Agung menggunakan standar penghitungan pangsa pasar dari seluruh wilayah Indonesia. Hal ini menunjukkan adanya perbedaan hasil penghitungan terhadap penguasaan pasar.

Kedua perbedaan putusan tersebut dapat dianalisis dari cara pengukuran pasar. KPPU telah melakukan pengukuran pasar dengan metode dan perhitungan yang standar dengan mengolah data dari berbagai sumber. KPPU menggunakan metode pengukuran rasio konsentrasi dengan pendekatan rasio konsentrasi empat perusahaan (CR4) dan Herfindahl-Hirschman Index (HHI) dan hanya menggunakan skala pasar di mana PT CI membuka outletnya. Sedangkan Mahkamah Agung lebih mempertimbangkan data dari AC Nielsen, MARS dan Euromonitor yang menggunakan skala pasar nasional. Perbedaan tersebut dikarenakan perbedaan tafsir mengenai "pasar bersangkutan" untuk mengukur skala pasar.

Dari kedua perbedaan putusan tersebut penulis berpendapat bahwa: pertama, sebaiknya ada metode dan cara pengukuran pasar yang standar dipakai dalam proses hukum persaingan usaha. Sehingga tidak menimbulkan dualism. Metode yang digunakan KPPU setidaknya lebih akurat dan dapat diuji secara metodologis karena diukur sendiri berdasarkan teori dan olahan berbagai data. Walaupun tentu saja mengandung nilai subjektivitas, namun hal tersebut lebih baik dari sekedar menggunakan data yang telah tersedia tanpa diolah.

Kedua, penfasiran mengenai skala pasar memang beragam dan kurang jelas untuk dijadikan 
standar. Karena secara teoritis pasar bisa dibedakan dalam berbagai skala, baik lokal nasional maupun internasional. Bahkan Faktanya Indonesia telah membuka pasar untuk wilayah ASEAN. Tetapi jika merujuk pada Pasal 1 huruf m disebutkan bahwa: "Pangsa pasar adalah persentase nilaijual atau beli barang atau jasa tertentu yang dikuasai oleh pelaku usaha pada pasar bersangkutan dalam tahun kalender tertentu." Sedangkan dalam huruf $\mathrm{j}$ yang dimaksud pasar bersangkutan adalah "pasar yang berkaitan dengan jangkauan atau daerah pemasaran tertentu oleh pelaku usaha atas barang dan atau jasa yang sama atau sejenis atau substitusi dari barang dan atau jasa tersebut." Kalimat "jangkauan atau daerah pemasaran tertentu" menunjukkan bahwa pasar bersangkutan bukanlah dalam perhitungan pasar keseluruhan secara nasional, namun lebih spesifik menunjukkan pada daerah atau jenis produk tertentu. Sehingga metode pengukuran pasar yang digunakan oleh KPPU menjadi lebih tepat.

\section{KESIMPULAN}

Dari pembahasan di atas dapat disimpulkan sebagai berikut:

1. Antara Putusan KPPU dan Mahkamah Agung menggunakan penafsiran gramatikal (tata bahasa), namun ada perbedaan dalam menginteprestasi teks Pasal 17 Undang-Undang Nomor 5 Tahun 1999. KPPU menafsirkan bahwa pelanggaran tersebut bersifat alternatif, yaitu PT CI sudah dianggap bersalah jika melanggar salah satu ayat. Sedangkan Mahkamah Agung menggunakan penafsiran bahasa secara kumulatif di mana pelanggaran terjadi ketika PT CI melanggar semua ayat tersebut. Selain itu Mahkamah Agung mengkaji putusan tentang entry barrier (menghambat masuknya pelaku usaha ke dalam pasar), Pasal 17 ayat (2) huruf b yang dirumuskan dengan pendekatan rule of reason. Sedangkan KPPU menggunakan ketentuan Pasal 25 ayat (1) huruf a UndangUndang Nomor 5 Tahun 1999 dirumuskan dengan pendekatan per se illegal.

2. Bahwa kedua putusan tersebut berbeda dalam memaknai pangsa pasar. KPPU menggunakan istilah pangsa pasar sebagai pasar di wilayah PT CI mempunyai usaha, yaitu hanya kota-kota tertentu, sedangkan Mahkamah Agung mengukur pangsa pasar menggunakan wilayah nasional. Namun jika dilihat dari ketentuan Pasal 1 huruf $\mathrm{j}$ dan huruf m, maka skala pasar berdasarkan daerah pemasaran tertentu dari suatu produk, bukan luasan pasar nasional.

\section{DAFTAR PUSTAKA}

Anggraini, A.M.T. (2003). Larangan praktikmonopoli \& persaingan tidak sehat: Per se illegal atau rule of reason. Jakarta: Fakultas Hukum Pasca Sarjana Universitas Indonesia.

Bishop, S., \& Walker. (2010). The economics of EC competition law: Concepts, aplication \& measurement. London: Sweet and Maxwell.

Black, H.C. (1990). Black's law dictionary, definition of the terms and phrases of American and English Jurisprudence, ancient \& modern. Minnesota: West Publishing Co.

Blundell, R., Griffith, R., \& Reenen, J.V. (1999). Market share, market value \& innovation in a panel of British Manufacturing Firms. The 
Review of Economic Studies, 66.

Cour, L.F.L., \& Møllgaard, H.P. (2002). Meaningful \& measurable market domination. Journal of Law and Economics. econ.ku.dk.

Fajrina, H.N. (2016, April 12). Alasan Alibaba akuisisi Lazada.Diaksesdarihttps://www.cnnindonesia. com/teknologi/20160412151635-185-123379/ alasan-alibaba-akuisisi-lazada/.

Halim, R. (2005). Hukum perdata dalam tanya jawab. Jakarta: Gitama Jaya.

Hermansyah. (2008). Pokok-pokok hukum persaingan usaha. Jakarta: Kencana.

Illiyyun. (2012). Revitalisasi pasar tradisional di Babat Kabupaten Lamongan. Undergraduate thesis. Malang: Universitas Islam Negeri Maulana Malik Ibrahim.

Irawanto, D.B. (2016). Analisis kinerja keuangan sebelum dan sesudah akuisisi PT. Bank Rakyat Indonesia Tbk. Jurnal Ilmu \& Riset Manajemen, 5(1).

Kasus akuisisi alfa, nasib carrefour ditentukan besok. (2009, November 2). Diakses dari http://finance. detik.com/berita-ekonomi-bisnis/1233654/ kasus-akuisisi-alfa-nasib-carrefour-ditentukanbesok?topnews.

Khemani, R.S., \& Shapiro, D.M. (1999). Glossary af industrial organisation economics \& Competition law. Paris: OECD.

Lubis, A.F. et al. (2009). Hukum persaingan usaha; Antara teks \& konteks. Jakarta: Komisi Pengawas Persaingan Usaha.

Mahkamah Agung RI [MA RI]. (2005). Naskah akademik tentang persaingan usaha \& anti monopoli. Jakarta: Mahkamah Agung RI.

Mailanto, A. (2016, April 14). Terungkap alasan XL Mengakuisisi Axis. Diakses dari https://techno. okezone.com/read/2016/04/14/54/1363222/ terungkap-alasan-xl-mengakuisisi-axis).

Margono, S. (2009). Hukum anti monopoli. Jakarta: Sinar Grafika.

Marzuki, P.M. (2016). Penelitian hukum. Jakarta: Prenadamedia Group.

Mertokusumo, S. (2003). Mengenal hukum. Yogyakarta: Penerbit Liberty.

Moin, A. (2010). Merger, akuisisi, \& disvestasi. Edisi Kedua. Yogyakarta: Penerbit Ekonosia.

Nugroho, S.A. (2014). Hukum persaingan usaha di Indonesia. Jakarta: Kencana Prenada Mediagrup.

Ramadhany, D. 2015. Harmonisasi pengaturan posisi dominan dalam ASEAN Economic Community ditinjau dari perspektif hukum persaingan usaha. Surabaya: Universitas Airlangga.

Reksohadiprodjo, S. (1999). Dasar-dasar manajemen. Edisi Kedua. Yogyakarta: BPFE.

Rokan, M.K. (2012). Hukum persaingan usaha, teori \& Praktiknya di Indonesia. Jakarta: Raja Grafindo Persada.

The Horizontal Merger Guidelines of Department of Justice and the Federal Trade Commission USA. (1992).

Wulandari, A.N. (2016). Analisis pemasaran \& strategi pengembangan rumput laut (Euchema Cottonii) di desa Tanjung Kecamatan Saronggi Kabupaten Sumenep. Jember: Universitas Jember.

Yani, A., \& Widjaja, G. (1999). Anti monopoli. Jakarta: Raja Grafindo Persada. 